\title{
'Double Skull' Appearance due to Calcifications of Chronic Subdural Hematoma and Cephalhematoma: A Report of Two Cases
}

\section{Kronik Subdural Hematom ve Sefallhematom Kalsifikasyonlarn Nedeniyle 'Çift Kafatası' Görünümü: İki Olgu Sunumu}

Vivek TANDON, Kanwaljeet GARG, Ashok Kumar MAHAPATRA

All India Institute of Medical Sciences, Department of Neurosurgery, New Delhi, India

Corresponding Author: Vivek TANDON / E-mail: drtandonvivek@gmail.com

\begin{abstract}
Chronic subdural hematomas and cephalhematomas are known to become calcified in some patients. We present interesting cases of cephalhematoma in a child and calcified chronic subdural hematoma in an elderly lady with both getting calcified. The first patient was a 7 months male with calcified cephalhematoma who presented with cosmetic deformity of the skull but did not have any neurological deficits. The other patient was a 54-year-old lady with calcified chronic subdural hematoma who presented with one episode of seizure but did not have any neurological deficit. CT scan revealed calcification of the hematoma causing a double skull appearance in both patients.
\end{abstract}

KEYWORDS: Cephalhematoma, Calcification, Subdural hematoma

öz

Kronik subdural hematomlar ve sefalhematomların bazı hastalarda kalsifiye olduğu bilinmektedir. Bir çocukta sefalhematom ve yaşlı bir kadında kronik subdural hematom bulunup her ikisinin kalsifiye olduğu ilginç olgular sunuyoruz. Birinci hasta kalsifiye sefalhematomlu 7 aylık bir erkekti ve herhangi bir nörolojik kusur olmadan kafatasının kozmetik deformitesi nedeniyle geldi. İkinci hasta kalsifiye kronik subdural hematomu olan 54 yaşında bir kadındı ve herhangi bir nörolojik defisiti olmadan bir nöbet episoduyla geldi. BT tarama her iki hastada çift kafatası görünümüne neden olan kalsifikasyon gösterdi.

ANAHTAR SÖZCÜKLER: Sefalhematom, Kalsifikasyon, Subdural hematom

\section{INTRODUCTION}

Cephalhematoma occurs due to hemorrhage from ruptured blood vessels that cross the periosteum of the skull. It is a subperiosteal collection of blood and therefore has defined boundaries and needs to be differentiated from caput succedaneum and chignon, which are swellings of the scalp. Calcification of the cephalhematoma can lead to persistent scalp swelling in a child.

Similarly, calcification of a chronic subdural hematoma is more frequently seen in children and young adults than in the aged (5). Seizures and mental retardation are more common symptoms of calcified chronic subdural hematomas in children, while they may present with mild symptoms or may even remain asymptomatic in adults (4).

We present two interesting cases of post-traumatic cephalhematoma and chronic subdural hematoma, in a 7 months child and a 54-year-old lady respectively. Calcification of these hematomas gave a double skull appearance on their CT scan.

\section{CASE REPORT 1}

This 7 months male child had history of a fall at the age of 15 days after birth, following which the parents had noticed a squishy swelling of the scalp in the parietal region. This swelling gradually became hard leading to abnormal appearance of the skull. On examination, the child had no neurological deficits. The scalp swelling was bony hard with well-defined margins. His computed tomography image revealed a calcified swelling of the scalp, giving a double skull appearance (Figure 1). A diagnosis of calcified cephalhematoma was made.

\section{CASE REPORT 2}

This 54-year-old lady presented with a history of one episode of generalized tonic clonic seizures but with no neurological deficits. On being probed, she gave a history of minor trauma to the head about 2 years back. Her CT scan revealed a calcified chronic subdural hematoma with midline shift to the opposite side, with open cisterns and easily seen sulci and gyri (Figure 2). This patient had no neurological deficits; therefore 
she was managed conservatively on antiepileptic drugs and had no recurrence of seizures at one-year follow-up.

\section{DISCUSSION}

The usual causes of cephalhematoma are prolonged second stage of labor or instrumental delivery, particularly after ventouse application (3). The child may develop jaundice, anemia or hypotension due to the hematoma. The swelling is usually resolved over a week as the blood clot gets slowly absorbed. At times the hematoma can get calcified, leading to a hardened mass of the skull. The collection of blood is subperiosteal in cephalhematoma. On the other hand,

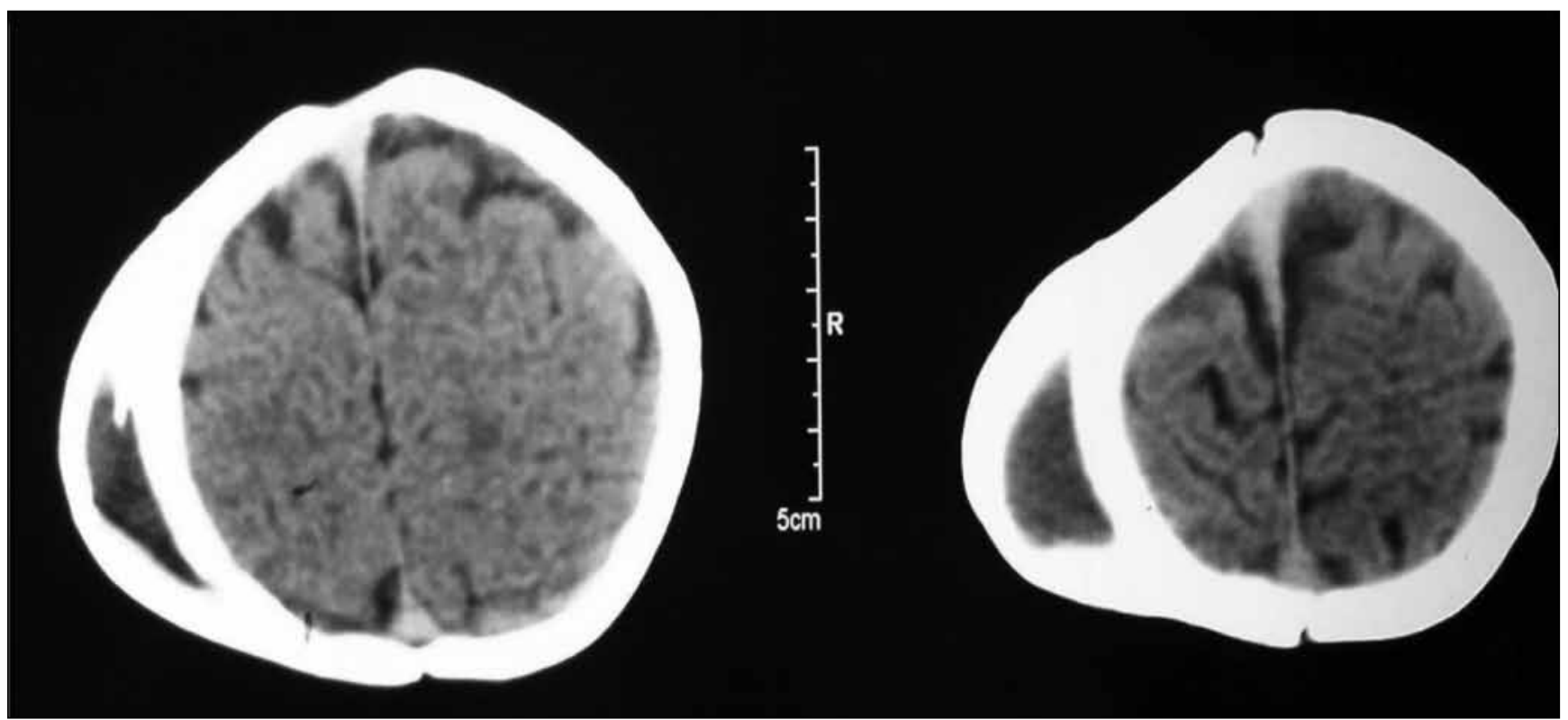

Figure 1: Computed tomography scan of 7-month-old male child showing calcified cephalhematoma giving rise to a 'double skull' appearance.

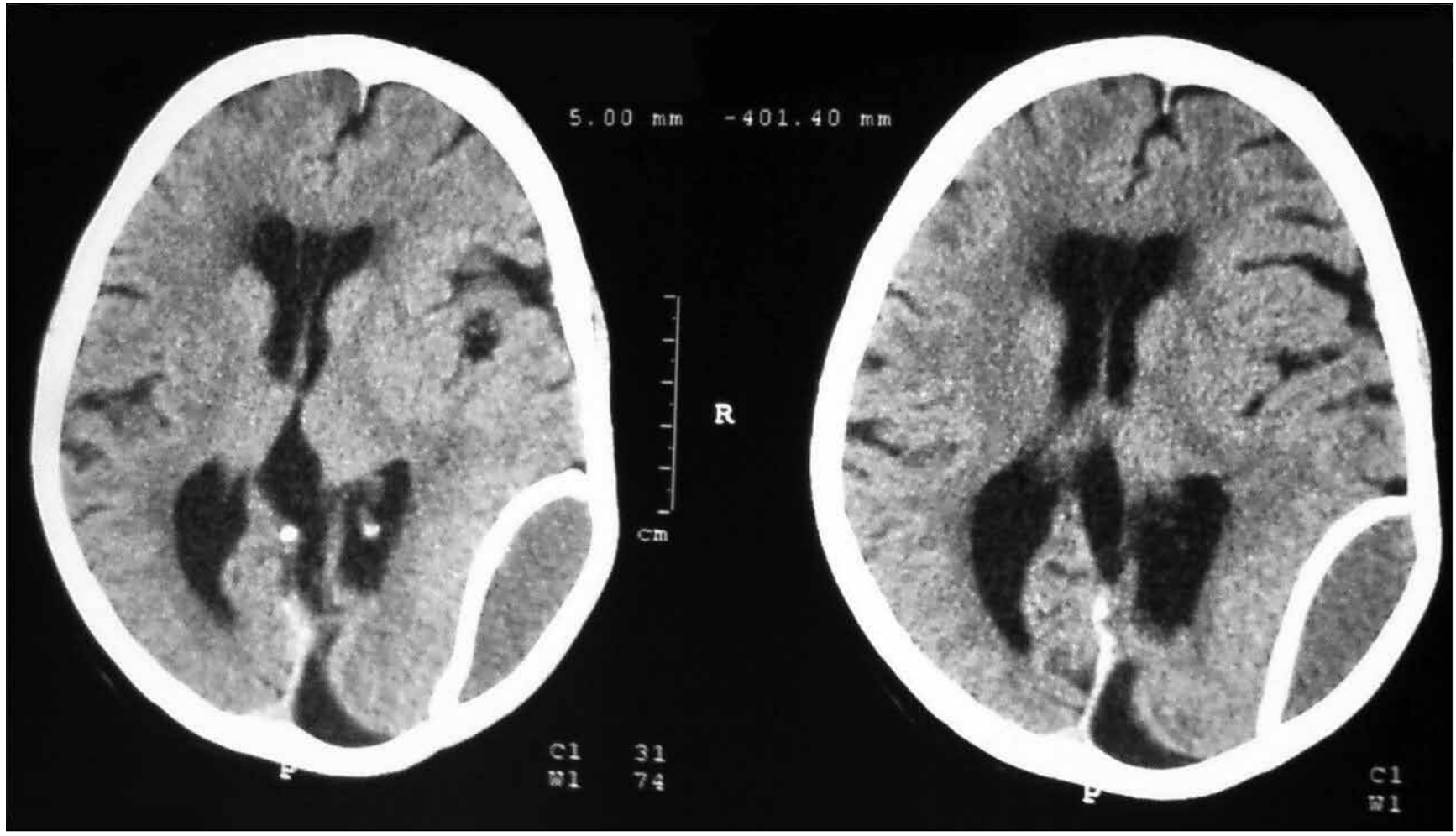

Figure 2: CT scan of a 54-year-old lady showing calcified subdural hematoma producing an appearance of 'double skull'. 
subgaleal collections of blood (caput succedaneum and chignon) are due to collection of blood in the loose areolar tissue between the galea and the periosteum. They can dissect a large area and cross suture lines. Cephalhematoma causes stripping of the periosteum layer that is limited to the sutures where the periosteum is densely adhered. This elevated periosteum can calcify and consequently such lesions can be misdiagnosed as intraosseous hematomas, arachnoid cysts, granulomatous lesions, or meningoencephaloceles $(6,7)$. Radiological studies like CT scan, MRI and even plain and tangential $X$ rays of the skull are helpful in differentiating the above lesions. CT scan of intraosseous hematomas demonstrates isodense areas while cephalhematomas tend to be hypodense to hyperdense and can resemble depression fractures if palpated. In their comparison, cephalhematoma is limited by suture lines and can be associated with linear fractures of the skull. Intraosseous hematomas on MRI are hypointense on T1- and hyperintense on T2-weighted images, but this is insufficient for differentiation. Rarely, biopsy may be needed to know the exact cause of scalp swelling (1).

Surgical resection of cephalhematoma is needed either for the above reason or for cosmetic purposes. Radiological follow up can be considered for calcified cephalhematomas, at least for a few months, because even spontaneous resolution has been reported in literature. Spontaneous resolution is explained by the tendency of the cranium under the ossified subperiosteum to grow, which gradually fills the space between the periosteum and cranium (1).

Radiologically demonstrable calcification of the chronic SDH membrane occurs in $0.3-2.7 \%$ cases of chronic SDH (8). An adhering calcification extending to the cerebral cortex corresponding to the inner membrane of chronic SDH is also called "armoured brain" (2) or "Matrioska head"(9). These names are given because the computed tomogram scan resembles a picture of another concentric skull inside the cranium. This is usually seen in subdural hematomas but can occur in postmeningitic subdural effusions as well (10). Development of calcification in hematoma may vary from 6 months to many years $(8,10)$. The underlying mechanism of calcification in these patients is unclear (2), and the presenting complains can range from being asymptomatic to those of raised intracranial pressure as well as seizures and mental retardation (10). Routine removal of these is not advocated as the surgical removal of the calcification is difficult and can cause damage to the cortex. The treatment of symptomatic expanding hematoma in these cases presents a challenge and may require a different approach than usual (2). Our patient had calcified chronic SDH that had failed to resolve but she had no neurological deficit and she was therefore treated conservatively (2).

Minor trauma to head was present in both of our patients history and it is likely that the cephalhematoma and chronic $\mathrm{SDH}$ might have become calcified and thus produced an interesting picture of a skull within a skull.

\section{REFERENCES}

1. Daglioglu E, Okay O, Hatipoglu HG, Dalgic A, Ergungor F: Spontaneous resolution of calcified cephalhematomas of infancy: Report of two cases. Turk Neurosurg 20:96-99, 2010

2. Dammers R, ter Laak-Poort MP, Maas AI: Neurological picture. Armoured brain: Case report of a symptomatic calcified chronic subdural haematoma. J Neurol Neurosurg Psychiatry 78:542-543, 2007

3. Gresham EL: Birth trauma. Pediatr Clin North Am 22:317-328, 1975

4. Ide $M$, Jimbo $M$, Yamamoto $M$, Umebara $Y$, Hagiwara S: Asymptomatic calcified chronic subdural hematoma--report of three cases. Neurol Med Chir (Tokyo) 33:559-563, 1993

5. Karvounis PC, Sakas DE, Singounas EG, Sourtzis I, Fotinou $M$ : Huge calcified subdural hematoma undetected for half a century. A case report in an old patient. Acta Neurol (Napoli) 9:212-217, 1987

6. Martinez-Lage JF, Lopez F, Piqueras C, Poza M: latrogenic intradiploic meningoencephalocele. Case report. J Neurosurg 87:468-471, 1997

7. Mobbs RJ, Gollapudi PR, Fuller JW, Dahlstrom JE, Chandran NK. Intradiploic hematoma after skull fracture: case report and literature review. Surg Neurol 54:87-91, 2000

8. Niwa J, Nakamura T, Fujishige M, Hashi K. Removal of a large asymptomatic calcified chronic subdural hematoma. Surg Neurol 30:135-139, 1988

9. Sgaramella E, Sotgiu S, Miragliotta G, Fotios Kalfas Crotti FM: "Matrioska head". Case report of calcified chronic subdural hematoma. J Neurosurg Sci 46:28-31; discussion 31, 2000

10. Sharma RR, Mahapatra A, Pawar SJ, Sousa J, Athale SD: Symptomatic calcified subdural hematomas. Pediatr Neurosurg 31:150-154, 1999 